\title{
Assessment of Heavy Metals in Waste-Water Irrigated Lettuce in Ghana: The Case of Tamale Municipality
}

\author{
Maxwell Anim-Gyampo ${ }^{1}$, Apori Ntiforo ${ }^{2} \&$ Michael Kumi $^{3}$ \\ ${ }^{1}$ Earth and Environmental Science Department, University for Development Studies, Navrongo, Ghana \\ ${ }^{2}$ Department of Applied Physics, University for Development Studies, Navrongo, Ghana \\ ${ }^{3}$ Environmental Chemistry Division, CSIR-Water Research Institute, Tamale, Ghana \\ Correspondence: Maxwell Anim-Gyampo, Earth and Environmental Science Department, University for \\ Development Studies, P. O. Box 24 Navrongo, Ghana. E-mail: gyampom@gmail.com
}

Received: September 14, 2012 Accepted: October 24, 2012 Online Published: October 30, 2012

doi:10.5539/jsd.v5n11p93

URL: http://dx.doi.org/10.5539/jsd.v5n11p93

\begin{abstract}
An assessment of some heavy metals concentrations in lettuce in irrigated with waste water in Tamale Metropolis in Ghana has been carried out. Analysis of water and lettuce samples revealed that the mean concentrations of $\mathrm{Fe}, \mathrm{Mn}, \mathrm{Cu}, \mathrm{Zn}, \mathrm{Cd}$ and $\mathrm{Pb}$ in lettuce were $0.436,0.345,0.068,0.017,0.04$ and $0.038 \mathrm{mg} / \mathrm{L}$ and $0.167,0.163,0.104,0.127,0.142$ respectively. With exception of $\mathrm{Mn}$ and $\mathrm{Cd}$, the concentrations of heavy metals in the irrigation water, irrigated soils and irrigated lettuce, were within the FAO recommended levels. The mean concentrations of nutrients $\left(\mathrm{NO}_{3}-\mathrm{N}, \mathrm{SO}_{4}\right.$ and $\left.\mathrm{PO}_{4}-\mathrm{P}\right)$ in the wastewater-irrigated lettuce, and well water-irrigated lettuce were $15.36,0.88,0.28$ and 19.09, 1.117, 0.0573 respectively. Though, heavy metals concentrations in the lettuce were low, regular monitoring are required to prevent heavy metal accumulation with their attendant health implications in the consuming public.
\end{abstract}

Keywords: Ghana, heavy metals, lettuce, Tamale Municipality, wastewater

\section{Introduction}

As demand for fresh water intensifies, the use of municipal or industrial waste water in agricultural sector is frequently being seen as a common practice in many parts of the world (Ensink et al., 2002; Sharma et al., 2007). An estimated twenty million hectares in 50 countries worldwide are irrigated with raw or partially treated waste water and this is likely to increase markedly during the next few decades as water stress intensifies (Hussein et al., 2001; Scott et al., 2004; Hamilton et al., 2007). The use of untreated and partially treated waste water for irrigation is particularly intense in arid and semi-arid regions and urban areas where unpolluted water is a scarce resource and waste-water enriched with nutrients is an important, drought-resistant resource for farmers (WHO, 2006). Plants have natural propensity to take-up metals, which are essential plant micronutrients while few others $\mathrm{Hg}, \mathrm{Cd}, \mathrm{Ni}$ and $\mathrm{Pb}$ are toxic to plants (Baker et al., 1991; Singh et al., 2003; Chen et al., 2005). Untreated wastewater may also contain a range of pathogens including bacteria, parasites, viruses, toxic chemicals from agriculture, industry and domestic sources (Amoah et al., 2010).

Previous studies in urban and peri-urban areas in Ghana had revealed that most surface water bodies used for irrigation may be heavily polluted and not suitable for crop irrigation. These irrigation waters are considered to contain hazardous chemicals, high levels of salts, harmful pathogens, decomposed human waste and a lot of other contaminants (Mensah et al., 2001; Cornish et al., 1999). In Tamale, the third largest city in Ghana (after Accra and Kumasi), the cultivation of common vegetables such as lettuce, spring onions, cabbage, carrots and green pepper etc. for consumption by inhabitants are produced from urban and peri-urban farms. These farms are generally sited along waste-water drains, near earth-dams with small reservoirs and broken-down sewers or near dug-outs (This situation is due to the fact that there is no perennial stream within the metropolis but rather, a few seasonal ones which are replenished during the rainy season and dry up in the prolonged dry season (IWMI, 2005). This situation is exacerbated by the occurrence of very low groundwater table within the municipality due to underlying consolidated neo-proterozoic Voltaian sedimentary formation, which is considered to be one of the least in terms of groundwater potential in Ghana (Gyau-Boakye \& Dapaah-Siakwan, 2000). 
The major vegetable growing farms within the metropolis are located in Builpela, Sangani, Gumbihene and Zagyuri. Farms in Builpela utilize water from earth-dam (small reservoir) for irrigation while Gumbihene, Sangani and Zagyuri utilize polluted water from an old dam, dug-outs and untreated sewage from a broken sewer for irrigation respectively. Even though, cultivation of fresh and raw-edible vegetables in the Tamale Metropolis has become a lucrative and attractive venture and a major source of income to otherwise poor farmers in the dry season, the cultivation and consumption of vegetables (mainly lettuce) from farms in and around Zagyuri community is of major public health concern since the source of irrigation water is from untreated sewer and Lettuce is one of the commonest vegetables that are cultivated within this suburb of Tamale Municipality. These farms are irrigated by the use of watering cans to splash water on the leaves of the lettuce and the soil, thereby exposing the fresh lettuce to potentially harmful and sometimes toxic pollutants that may include toxic heavy metals such as $\mathrm{Pb}, \mathrm{Cd}, \mathrm{Cu}, \mathrm{Fe}, \mathrm{Mn}$ and $\mathrm{Zn}$ and pathogens, which may pose serious health risks not only to the farmers but also to fast food operators, vegetable vendors and the consuming public. The danger is that lettuce is mostly consumed in its raw state (fresh) and not cooked, whether at homes, most public eating places or in restaurants in Tamale and virtually in the entire country. This study therefore seeks to assess concentrations of heavy metal levels in lettuce cultivated using irrigated waters from untreated sewers and the potential health implications for human consumers within the vicinity of Tamale Metropolis and its environs.

\section{Material and Methods}

\subsection{The Study Area}

The Tamale Metropolis is the regional capital of the Northern Region of Ghana, and the third largest city in Ghana. It is made up of about 197 communities of which 33 are within the urban, and the remaining being peri-urban and rural. The Metropolis is located in the central part of the Northern Region. It is approximately $930 \mathrm{~km}^{2}$ and lies between latitude $9^{\circ} 16^{\prime} \mathrm{N}$ and $9^{\circ} 34^{\prime} \mathrm{N}$ and longitudes $0^{\circ} 36^{\prime} \mathrm{W}$ and $0^{\circ} 57^{\prime} \mathrm{W}$ respectively. It is bounded to the north by Savelugu- Nanton District, to the East by Yendi Municipality, to the West by Tolon-Kumbungu District, south by Central Gonja and East Ganja Districts (Agodzo et al., 2003). The climate is characterised by a single raining season from April/May to September/October, under the influence of moist south westerly (monsoon) winds originating from the Atlantic Ocean with a mean annual rainfall of about $1100 \mathrm{~mm}$ followed by a prolonged dry season which is under the influence of the dry northeasterly (Harmattan) trade winds originating from the Sahara desert and is laden with sandstorm from November-March and high sunshine from March-May.

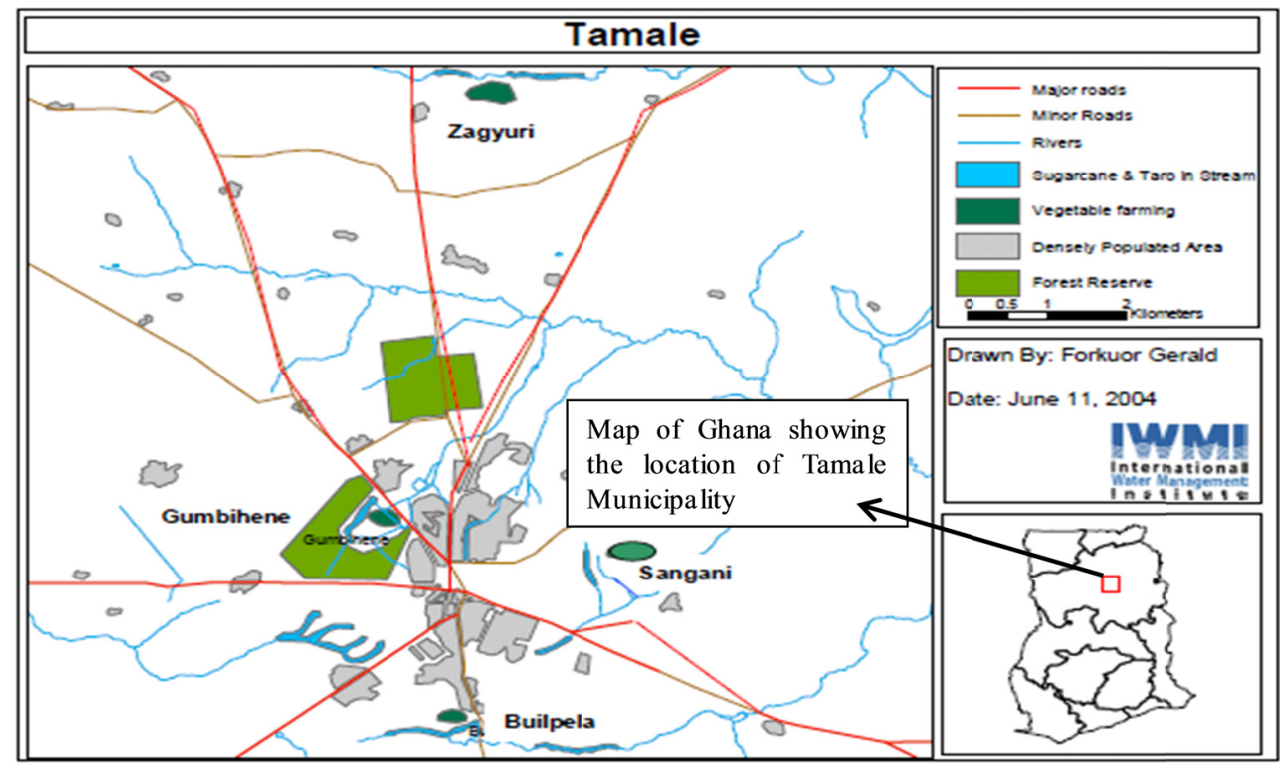

Figure 1. Location of study area

The mean daily temperatures range between $33-39^{\circ} \mathrm{C}$ while mean night temperatures range from $20-22^{\circ} \mathrm{C}$. The vegetation is Guinea Savanna Woodland which is characterised by tall grass interspersed with drought-resistant 
trees such as Neem, Shea tree, Dawadawa, Baobab, Acacia and Mahogany (Dickson \& Benneh, 1985). The area is generally flat and rolling with some shallow valleys which serve as stream channels with some few isolated hills rising to about $180 \mathrm{~m}$ above mean sea level. The Metropolis is poorly drained with few natural seasonal streams which have water during the rainy season and dry up during the dry season. Notably among these are Pasam, Dirm-Nyogni and Kwaha. There are dug-outs which serve as sources of water for domestic purposes, livestock, and watering of vegetables. These dams include the Builpela and Lamashegu dams with about ninety-one (91) dug-outs dotted around communities within the metropolis. The study area is underlain by the Neo-proterozoic Upper Voltaian sedimentary formation, which is composed of quartzites, sandstones and shales which are fairly hard and well consolidated and therefore inherently impermeable. Groundwater potential is among the least in Ghana (Dapaah-Siakwan \& Gyau-Boakye, 1998) due to the generally impervious underlying thick shale formation while reasonable groundwater is encountered in fractured and well-jointed sandstones and permeable planes along contacts between quartzites, sandstone with other rock formation. The common soil type is sand, clay and lateritic ochrosols.

\subsection{Field Sampling}

Zagyuri, near Kamina Barracks in the northern part of Tamale Metropolis is one of the major vegetable growing sites in urban Tamale (Figure 1). The others include Gumbihene, Builpela and Sangani. The farming site has a total area of 12 ha (Zibrilla \& Salifu, 2004). The sources of water for irrigation are mainly untreated wastewaters from broken sewage pipes at the Kamina Military Barracks and surrounding communities and on minor scale from hand-dug wells, which had been constructed on the various farms within the site for the purpose of washing the harvested vegetables of accumulated dirt and insects. The main vegetables produced from these farms include lettuce, cabbage and spring onions. The wastewater is directed through the irrigation channels into the fields where farmers fetch to irrigate their crops and the bulk of the volume of wastewater is stored in unprotected concrete ponds as reservoirs. Samples of irrigation waters were obtained from the broken sewer and shallow well where farmers fetch water to irrigate their vegetables. Soil samples at a depth of $10 \mathrm{~cm}$ were collected at each irrigated water site, using sterile spatulas and $60 \mathrm{~mm}$ diameter soil auger. Lettuce heads from farms at each irrigated water site were randomly collected. Wastewater and well water samples were collected in $250 \mathrm{~mL}$ plastic containers previously cleaned by washing in non-ionic detergent, rinsed up with tap water and later soaked in $10 \% \mathrm{HNO}_{3}$ for 24 hours and finally rinsed with de-ionised water prior to usage. All water samples for heavy metal analysis were acidified $(\mathrm{pH}<2)$ by adding $1 \mathrm{ml}$ of concentrated $\mathrm{HNO}_{3}$. Sample bottles were rinsed with sampled water three times and then filled to the brim at a depth of $50 \mathrm{~cm}$ below the water at each sample point, labeled and transported in ice-chest at a temperature of about $4{ }^{\circ} \mathrm{C}$ to the laboratory (CSIR-WRI Laboratory, Tamale) for analysis.

\subsection{Analysis of Water, Soil and Lettuce Samples}

\subsubsection{Physical Parameters and Heavy Metals}

Temperature and $\mathrm{pH}$ were determined in-situ, using a mercury-in-glass thermometer Hanna portable $\mathrm{pH}$ meter respectively. A multipurpose electronic Jenway 4520 conductimeter was used to measure the conductivity, salinity, and TDS of all samples. A 2100P turbidimeter was also used in determining the turbidity of all samples. EDTA Titration was used to determine the water hardness. The analyses of heavy metals $(\mathrm{Fe}, \mathrm{Mn}, \mathrm{Zn}, \mathrm{Cu}, \mathrm{Pb}$ and Cd) were performed in accordance with APHA-AWWA-WEF, 2001, using Shimadzu Atomic Absorption Spectrophotometer (AAS)-AA 6300 model. The concentrations of nutrients (nitrate, sulphate and phosphate) were done using Jenway 6405 UV/VIS Spectrophotometer. Nitrate as nitrogen was determined by the Hydrazine Reduction Method (Standard Methods, APHA, AWWA, WEF, (1995)). While phosphate was determined using the Stannous Chloride Method (Standard Methods, APHA, AWWA, WEF, (1998)).

\subsubsection{Digestion of Soil Samples for Analysis}

$50 \mathrm{~g}$ of soil at each irrigated water site on the farm were obtained by the use of sterile spatulas and $60 \mathrm{~mm}$ diameter soil auger and immediately wrapped in polythene bags and sealed air-tight for laboratory analysis. The soils were air-dried for 24 hours, grounded, homogenized and sieved through a $0.4 \mu \mathrm{m}$-mesh to remove debris such as roots, leaves and large stone. $0.2 \mathrm{~g}$ of the sieved soil sample was placed in Teflon tubes, and $2 \mathrm{mls}$ of concentrated $\mathrm{HNO}_{3}$ was added to the soil in the tube. The Teflon tube was closed and placed on stainless bombs, which was then placed on a hot plate and heated to a temperature of $150^{\circ} \mathrm{C}$ for seven hours. The bombs were opened after it had cooled to room temperature and pressure had been released. The digested soil samples were transferred into a polypropylene graduated tube and the Teflon tube rinsed three times with deionized water. The rinsed waters were then added to the polypropylene tube content. The solution was diluted to the $25 \mathrm{~mL}$ mark of 
the tube with deionized water and mixed thoroughly. The particles were allowed to settle overnight, filtered to remove any insoluble materials that could clog the atomizer for analysis.

\subsubsection{Digestion Lettuce Samples for Analysis}

The lettuce leaves were oven-dried for 2 days at a temperature of $80^{\circ} \mathrm{C}$. It was ground, homogenized and sieved to remove all debris. $0.2 \mathrm{~g}$ of the sieved lettuce sample was weighed into Teflon tubes using Adam's Equipment ADA 210/LE electronic scale. A volume of $2 \mathrm{~mL}$ conc. of $\mathrm{HNO}_{3}$ was added to the lettuce in the Teflon tube. The tube was closed and placed in stainless bombs. The stainless bomb was then placed on a hot plate and heated at $110^{\circ} \mathrm{C}$ for $30 \mathrm{~min}$ and then $150^{\circ} \mathrm{C}$ for $2 \mathrm{hrs}$. The bomb was opened after it had been allowed to cool to room temperature and the pressure had been released. The digested sample was then transferred into polypropylene graduated tube and the Teflon was rinsed three times with demonized water. The rinsing water was also added to the polypropylene tube. This solution was then diluted to the $25 \mathrm{~mL}$ mark of the tube with deionized water and mixed thoroughly. The particles were allowed to settle overnight, filtered to remove any soluble materials that might clog the atomizer during analysis.

\section{Results}

The results of laboratory analysis of types of irrigation waters and cultivated lettuce in the study area are presented in Tables 1-5. The mean $\mathrm{pH}$ value for wastewater and shallow well water were 7.58 and 7.25 respectively (Table 1) while soils irrigated with wastewater and well water were 7.57 and 7.52 respectively (Table 2). The mean electrical conductivity for wastewater and well water were $639 \mu \mathrm{S} / \mathrm{cm}$ and $482 \mu \mathrm{S} / \mathrm{cm}$ respectively while turbidity values were 107.67NTU and 19NTU respectively (Table 1). The concentrations of nitrate, sulphate and phosphate in all the sampling points varied between 6.88 to $22.86 \mathrm{mg} / 1$ for nitrate, 0.18 to $1.20 \mathrm{mg} / \mathrm{l}$ for sulphate and 0.05 to $0.55 \mathrm{mg} / \mathrm{l}$ for phosphate respectively (Table 3 ). The mean concentrations of the heavy metals $(\mathrm{Fe}, \mathrm{Mn}, \mathrm{Cu}, \mathrm{Zn}, \mathrm{Cd}$ and $\mathrm{Pb}$ ) irrigated with irrigation water sources including in the lettuce were recorded as 0.010 to $1.604 \mathrm{mg} / \mathrm{l}, 0.188$ to $0.607 \mathrm{mg} / \mathrm{l}, 0.037$ to $0.100 \mathrm{mg} / \mathrm{l}, 0.005$ to $0.054 \mathrm{mg} / 1,0.028$ to 0.063 $\mathrm{mg} / \mathrm{l}$ and 0.010 to $0.020 \mathrm{mg} / \mathrm{l}$ respectively (Table 4 ).

Table 1. Levels of physical parameters of irrigated water sources

\begin{tabular}{|c|c|c|c|c|c|c|c|}
\hline \multirow{2}{*}{ Physical Parameters } & \multirow{2}{*}{ Unit } & \multicolumn{4}{|c|}{ Waste water } & \multirow{2}{*}{ Range } & \multirow{2}{*}{ Shallow well } \\
\hline & & WW1 & WW2 & WW3 & Mean & & \\
\hline Temperature & ${ }^{\circ} \mathrm{C}$ & 45.2 & 45.8 & 46.3 & 45.77 & $45.2-46.3$ & 41.11 \\
\hline TDS & $\mathrm{mg} / 1$ & 292 & 424 & 429 & 381.67 & $292-429$ & 289 \\
\hline $\mathrm{EC}$ & $\mu \mathrm{S} / \mathrm{cm}$ & 488 & 711 & 718 & 639 & $488-718$ & 482 \\
\hline $\mathrm{pH}$ & & 7.51 & 7.6 & 7.64 & 7.58 & $7.51-7.6$ & 7.25 \\
\hline Turbidity & NTU & 118 & 126 & 79 & 107.67 & $79-126$ & 19 \\
\hline
\end{tabular}

Table 2. Physical parameter in the irrigated soils

\begin{tabular}{lccc}
\hline & Values & pH & EC $(\boldsymbol{\mu S} / \mathbf{c m})$ \\
\hline \multirow{2}{*}{ Wastewater } & Range & $7.38-7.75$ & $626-933$ \\
& Mean & 7.57 & 779.50 \\
\hline \multirow{2}{*}{ Well water } & Range & $7.28-7.76$ & $745-922$ \\
& Mean & 7.52 & 833.5 \\
\hline
\end{tabular}


Table 3. Mean concentrations of nutrients in irrigation water and irrigated lettuce

\begin{tabular}{cccc}
\hline Nutrients & Value & Irrigation water $(\mathbf{m g} / \mathbf{L})$ & Irrigated lettuce $(\mathbf{m g} / \mathbf{L})$ \\
\hline \multirow{2}{*}{ Nitrate } & Range & $6.88-22.86$ & $4.438-37.81$ \\
& Mean & 15.3625 & 19.093 \\
\multirow{2}{*}{ Sulphate } & Range & $0.18-1.20$ & $0.001-6.034$ \\
& Mean & 0.8825 & 1.1177 \\
\multirow{2}{*}{ Phosphate } & Range & $0.05-0.55$ & $0.001-0.176$ \\
& Mean & 0.2800 & 0.0573 \\
\hline
\end{tabular}

Table 4. Mean concentrations of heavy metals in irrigation water, soil and lettuce

\begin{tabular}{|c|c|c|c|c|c|}
\hline Heavy metal & Value & $\begin{array}{c}\text { Water } \\
\text { source }(\mathbf{m g} / \mathbf{L})\end{array}$ & $\begin{array}{c}\text { Irrigated } \\
\text { soil }(\mathrm{mg} / \mathrm{L})\end{array}$ & Irrigated lettuce $(\mathrm{mg} / \mathrm{L})$ & WHO/FAO Guideline \\
\hline \multirow{2}{*}{$\mathbf{F e}$} & Range & $0.167-0.436$ & $170-196$ & $0.010-1.604$ & 5.0 \\
\hline & Mean & 0.3015 & 181.867 & 0.436 & \\
\hline \multirow{2}{*}{ Mn } & Range & $0.163-0.345$ & $5.24-12.79$ & $0.188-0.607$ & 0.20 \\
\hline & Mean & 0.254 & 9.333 & 0.345 & \\
\hline \multirow{2}{*}{$\mathbf{C u}$} & Range & $0.0678-0.104$ & $0.030-0.036$ & $0.037-0.100$ & 0.20 \\
\hline & Mean & 0.086 & 0.033 & 0.0678 & \\
\hline \multirow{2}{*}{$\mathbf{Z n}$} & Range & $0.0127-0.017$ & $0.154-0.265$ & $0.005-0.054$ & 2.0 \\
\hline & Mean & 0.0149 & 0.199 & 0.017 & \\
\hline \multirow{2}{*}{ Cd } & Range & $0.0142-0.040$ & $0.030-0.036$ & $0.028-0.063$ & 0.01 \\
\hline & Mean & 0.027 & 0.033 & 0.040 & \\
\hline \multirow{2}{*}{$\mathbf{P b}$} & Range & $0.005-0.038$ & $0.020-0.106$ & $0.010-0.020$ & 5.0 \\
\hline & Mean & 0.021 & 0.052 & 0.012 & \\
\hline
\end{tabular}

\section{Discussions}

\subsection{Physical Parameters}

Both irrigation water sources and irrigated soils were slightly basic with the mean $\mathrm{pH}$ values ranging from 7.25 to 7.58 , which fell within the tolerance range of $6.82-8.85$ for waste water to be discharged into channel or stream (WHO, 2007). The mean temperatures of $45.77^{\circ} \mathrm{C}$ and $41.11^{\circ} \mathrm{C}$ for wastewater and shallow well water respectively were found to be above the recommended W.H.O guideline of $40^{\circ} \mathrm{C}$ for discharge of wastewater into stream Temperature is basically important for its effects on other properties of water. These results indicate that some reactions could be speeded up by the discharge of wastewater and the well water into streams. It could also reduce the solubility of oxygen and amplify odour due to anaerobic reaction (less oxygen). The mean turbidity values of the wastewater far exceeded that of the shallow well water with both sources having mean values of 107.67NTU and 19NTU, which are above the recommended limit of 5NTU for discharged wastewater into stream. The mean conductivity values of $639 \mu \mathrm{S} / \mathrm{cm}$ and $482 \mu \mathrm{S} / \mathrm{cm}$ are far above the W.H.O guideline values of $100 \mu \mathrm{S} / \mathrm{cm}^{3}$ for discharge of wastewater through channel into stream. These values indicate that in terms of salinity, all the water sources are not suitable for discharge into stream and for irrigation (Kandiah, 1990b).

\subsection{Nutrients}

The mean levels of nitrate exceeded the WHO limits of $10 \mathrm{mg} / 1$ for nitrate in wastewater while sulphate was below the WHO limit of $250 \mathrm{mg} / 1$ for discharge of wastewater into river. The levels of phosphate in the entire sampling points were high above the WHO limit of $0.005 \mathrm{mg} / 1$ for the discharge of wastewater into river. The results also indicate that concentrations of nitrate, sulphate and phosphate were detected in the lettuce samples. The concentration of nutrients in both the irrigation water and the lettuce are in the order $\mathrm{NO}_{3}-\mathrm{N}>\mathrm{SO}_{4}>\mathrm{PO}_{4}-\mathrm{P}$. 
From the results of this study, $\mathrm{NO}_{3}-\mathrm{N}$ recorded the highest concentration in the irrigation water source and the irrigated lettuce. Thus, the continuous consumption of lettuce from study by young babies might expose them to methaemoglobinemia especially due to nitrate interfering with iron in the blood which results in defective transport of oxygen (WHO, 2007). Also ingestion of nitrate can contribute to gastric cancer when some of the nitrates are converted into nitrosamines which are thought to be carcinogens (Haiyan \& Stuanes, 2003; Speijers, 1996). Furthermore, the levels of nitrate reported in this study have the potential of causing eutrophication.

\subsection{Concentrations of Heavy Metals in Irrigation Water Sources}

The dominance of heavy metals in the different sources of irrigation water were in the trend $\mathrm{Fe}>\mathrm{Mn}>\mathrm{Cu}>\mathrm{Cd}>\mathrm{Pb}>\mathrm{Zn}$ (Table 5). The concentrations of $\mathrm{Cu}, \mathrm{Zn}, \mathrm{Fe}$ and $\mathrm{Pb}$ in all the water sources were far below the recommended levels (Table 5) while that of $\mathrm{Mn}$ and $\mathrm{Cd}$ were slightly above the WHO recommended levels of 0.05 and $0.003 \mathrm{mg} / \mathrm{L}$ respectively. There was no significant difference in the $\mathrm{Mn}$ and $\mathrm{Cd}$ concentration between waste water and well water. The relatively higher concentration of $\mathrm{Mn}$ in the wastewater and well water could be attributed to the influence of domestic effluents from Kamina wastewater channel as observed by Cornish et al. (1999).

\subsection{Concentrations of Heavy Metals in Irrigated Soils}

The irrigated soils contained the highest concentrations of heavy metals compared to the different irrigation water sources and the irrigated lettuce, with dominance in the order of $\mathrm{Fe}>\mathrm{Mn}>\mathrm{Zn}>\mathrm{Cu}>\mathrm{Cd}>\mathrm{Pb}$. This is consistent with the findings of Alexander et al. (2006), which concluded that the concentrations heavy metals found in the soil irrigated with wastewater were higher than concentrations found in the soil irrigated with well water and that leafy vegetables are higher accumulators of metal ions as compared to root vegetables and legumes. Studies have shown that observed higher heavy metals concentrations in wastewater irrigated soils may mostly be due to the accumulation of heavy metals from infiltrating wastewater, which may often be loaded with heavy metals for crop production and which may be bioavailable to crops with time (Toze, 2004). Irrigation of crops via wastewater therefore may poses potential threats to the environment through contamination by nutrients, heavy metals, salts and nitrates (Stagnitti et al., 1998). It also poses a number of potential risks to human health via the consumption of or exposure to pathogenic microorganisms, heavy metals or harmful organic chemicals (Stagnitti, 1999). According to WHO (2006), the concentrations of toxic chemicals vary from place to place, depending on their sources discharge of effluents into the wastewater and extent of treatment prior to heavy metal concentrations in the leaves and seeds of fibre crops grown on heavily polluted soil have been found to be lower than concentrations present in soil (Angelova et al., 2004). The differences in the concentrations in the lettuce irrigated with different water sources and that of the soils depends on the physical and chemical nature of the soil and absorption capacity of each metal by the vegetable and these are usually considered to be influenced by various factors such as the environment and human interference (Zurera et al., 1989). The high levels of heavy metals observed in the irrigated soils are an indication of the fact that the site where the study was carried out had been contaminated or polluted with heavy metals. The generally low levels of heavy metals however may indicate the existence of little or no industrial activities such as battery production, metal production, metal smelting and cable coating which are known to be major contributing factors for these metals in the environment (Bigdeli \& Seilsepour, 2008).

\subsection{Concentration of Heavy Metals in Irrigated Lettuce}

Generally, the concentrations of heavy metals were observed to be higher in irrigated lettuce than in the different waters (wastewater and shallow well water) used for irrigation (Table 4). The mean concentrations of heavy metals in the irrigated lettuce from both waste and shallow well waters sources are in order of $\mathrm{Fe}>\mathrm{Mn}>\mathrm{Cu}>\mathrm{Pb}$ $>\mathrm{Cd}>\mathrm{Zn}$. Furthermore, the concentrations of heavy metals in lettuce irrigated with wastewater were observed to be higher than lettuce irrigated with shallow well water (Table 5). Even though, comparatively higher concentrations of heavy metals were detected in the irrigated lettuce, their levels, with the exception of $\mathrm{Mn}$ and $\mathrm{Cd}$ (Figure $2 \& 3$ ) were generally below the WHO/FAO recommended levels for trace elements in vegetables (Table 5). According to Ghesquiere (1999), no health risk has been associated with food containing high Mn concentrations. However, high concentration of Mn can be toxic to some plants (Pescod, 1992). 
Table 5. Concentrations of heavy metals in cultivated lettuce

\begin{tabular}{llll}
\hline Irrigated lettuce & Heavy metals & Range $(\mathbf{m g} / \mathbf{L})$ & Mean $(\mathbf{m g} / \mathbf{L})$ \\
\hline & $\mathrm{Fe}$ & $<0.010-1.604$ & 0.436 \\
& $\mathrm{Mn}$ & $0.188-0.607$ & 0.345 \\
Lettuce irrigated with wastewater & $\mathrm{Cu}$ & $0.037-0.100$ & 0.0678 \\
& $\mathrm{Zn}$ & $<0.005-0.054$ & 0.017 \\
& $\mathrm{Cd}$ & $0.028-0.063$ & 0.040 \\
& $\mathrm{~Pb}$ & $0.03-0.07$ & 0.038 \\
& $\mathrm{Fe}$ & $0.010-0.284$ & 0.167 \\
& $\mathrm{Mn}$ & $0.102-0.240$ & 0.163 \\
Lettuce irrigated with well water & $\mathrm{Cu}$ & $0.003-0.240$ & 0.104 \\
& $\mathrm{Zn}$ & $0.004-0.045$ & 0.0127 \\
& $\mathrm{Cd}$ & $0.005-0.040$ & 0.0142 \\
& $\mathrm{~Pb}$ & $0.010-0.020$ & 0.00195 \\
\hline
\end{tabular}

The mean concentrations of the heavy metals detected in the irrigation water, soils and lettuce are in the trend $\mathrm{Fe}>\mathrm{Mn}>\mathrm{Cu}>\mathrm{Cd}>\mathrm{Zn}>\mathrm{Pb}$. Heavy metals, which are commonly found in domestic, industrial and municipal waste discharges, can be hazardous (toxic) to consumers of vegetables and other produce cultivated using wastewater (Abdulla \& Chmielnicka, 1990). Heavy metals are present in food in very minute quantities; the existence is due to their role in body metabolism. It has been established that whatever is taken as food might cause metabolic disturbance if it does not contain the permissible upper and lower limit of heavy metals. Thus, both deficiency and excess of essential micro-nutrients (iron, zinc and chromium) may produce undesirable effects (Konofal et al., 2004; Kocak et al., 2005). Living organisms require some level of heavy metals in the right concentrations as micronutrients for proper development, but with concentration above acceptable quantities may produce serious health consequences. The continuous consumption of vegetables contaminated with heavy metals such as $\mathrm{Pb}$ and $\mathrm{Cd}$ can be neurotoxic, carcinogenic and their occurrence could affect the central nervous system, the endocrine system of humans and the occurrence of cognitive impairments in children (Weiss, 2000; Koger et al., 2005).

Table 6. Concentrations of heavy metals in irrigation water sources

\begin{tabular}{cccc}
\hline Parameter & Waste Water $(\mathbf{m g} / \mathbf{L})$ & Well Water $(\mathbf{m g} / \mathbf{L})$ & WHO Guideline $(\mathbf{m g} / \mathbf{L})$ \\
\hline $\mathbf{C u}$ & 0.073 & 0.089 & 2.00 \\
$\mathbf{F e}$ & $<0.010$ & $<0.010$ & 0.30 \\
$\mathbf{M n}$ & 0.084 & 0.086 & 0.05 \\
$\mathbf{C d}$ & 0.105 & 0.124 & 0.003 \\
$\mathbf{Z n}$ & $<0.005$ & $<0.005$ & 0.03 \\
$\mathbf{P b}$ & $<0.005$ & $<0.005$ & 0.05 \\
\hline
\end{tabular}




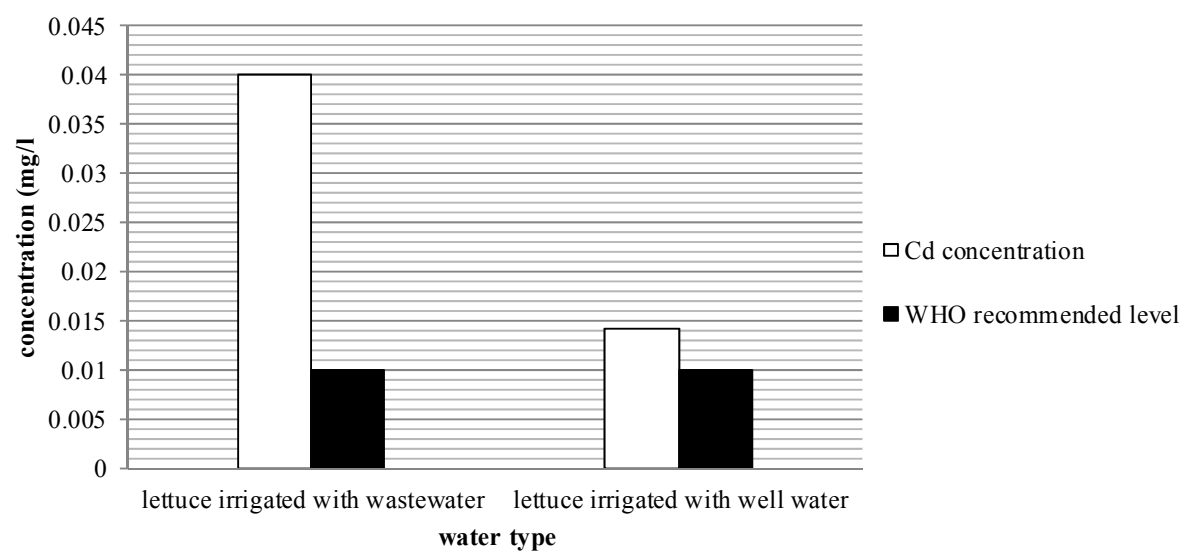

Figure 2. Mean concentration of cadmium in lettuce irrigated with different water types

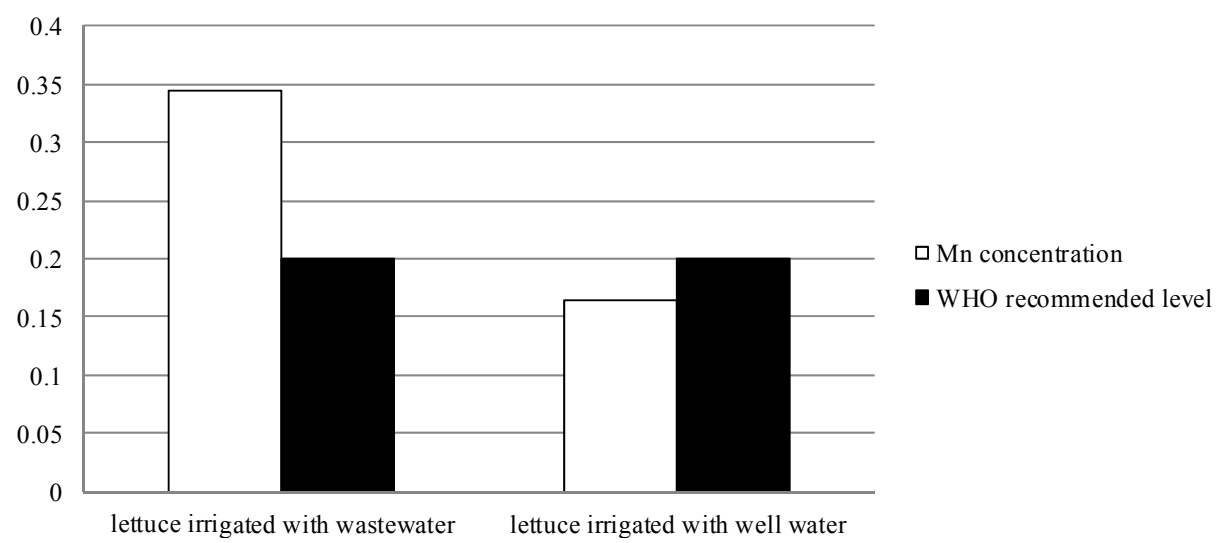

Figure 3. Mean concentration of manganese in lettuce irrigated with different water sources

\section{Conclusion}

From the results of this study, the concentration of physical parameters ( $\mathrm{pH}, \mathrm{EC}$, Turbidity and Temperature) found in the irrigation water sources were generally above the limits set by WHO for the discharge of wastewater into surface water. The measured mean concentration of Nitrate-nitrogen and phosphate in irrigated lettuce were observed to be higher than WHO recommended level. The high nitrate concentration may result in methaeglobinemia in young babies (blue baby syndrome) and can contribute to development of gastric cancer in adults. Sulphate levels in the irrigated lettuce fell within the recommended limits of WHO guidelines with the exception of $\mathrm{Mn}$ and $\mathrm{Cd}$, the concentrations of all the measured heavy metals were within the recommended limits of WHO/FAO guidelines. This suggests that the wastewater and the well water used for irrigation of these lettuce samples within the study area can be classified as unfit for irrigation of crops. The high concentrations of heavy metals ( $\mathrm{Fe}, \mathrm{Mn}, \mathrm{Cu}, \mathrm{Zn}, \mathrm{Cd}$ and $\mathrm{Pb}$ ) in the irrigated soils and the significant levels in irrigated lettuce in the study area may due mostly to the accumulation of heavy metals in the soil due to the continuous usage of wastewater as the main irrigation water source and the resulting bioaccumulation by lettuce from the contaminated soil as well as sprinkled wastewater on the leaves of the lettuce from the broken sewer from Kamina barracks and its environs. There is significant level of soil pollution as shown by the elevated concentrations of heavy metals in the soils.

\section{Recommendation}

The data generated must be used as baseline wastewater quality framework to serve as a basis for monitoring irrigation water quality in the Tamale metropolis to ensure safety. Responsible agencies should carry out public health education within Tamale metropolis to sensitise the general public on the potential effects of indiscrimate disposal of waste and the potential health hazards associated with the consumption of lettuce cultivated with wastewater. Measures must be taken to reduce heavy metal pollution and nutrient loading of irrigation water and 
soils to protect the safety of both farmers and consumers of lettuce as well as agro-ecological resources including aquatic life.

\section{References}

Abudulla. M., \& Chmielnicka, J. (1990). New Aspects on the distribution and metabolism on essential trace elements after dietary exposure to toxic metals. Biol. Trace-Element Res., 23, 25-53. http://dx.doi.org/10.1007/BF02917176

Alexander, P. D., Aloway, B. J., \& Dourado, A. M. (2006). Genotype variations in the accumulation of Cd, Cu, $\mathrm{Pb}$ and $\mathrm{Zn}$ exhibited by six commonly grown vegetables. Environ. Pollut., 144(3), 736-745. http://dx.doi.org/10.1016/j.envpol.2006.03.001

Amoah, P., Drechsel, P., \& Abaidoo, R. C. (2005). Irrigated Urban Vegetable Production in Ghana: Sources of pathogen contamination and health risk reduction: Irrig. Drainage, 54, 49-61. http://dx.doi.org/10.1002/ird.185

Angelova, V., Ivanov, V., Delibaltova, \& Ivanov, K. (2004). Bio-accumulation and distribution of heavey metals in fibre crops (flax, cotton and hemp). Ind. Crops Pro., 19, 197-205. http://dx.doi.org/10.1016/j.indcrop.2003.10.001

APHA-AWWA-WEF. (1998). Standard Methods for Examinations of Water and Wastewater, (20th ed., pp. 4-146). Washington D.C.

APHA-AWWA-WEF. (2001). Standard Methods for Examinations of Water and Wastewater, (22nd ed., pp. 4-146). Washington D.C.

Bigdeli, M., \& Seilsepour, M. (2008). Investigation of metal accumulation in some vegetables irrigated with wastewater in Shahre rey-iran and toxicological implications. Am. Euras. J. Agric. Env. Sci., 4(1).

Chen, Y., Wang, C., \& Wang, Z. (2005). Residues and source identification of persistent organic pollutants in farmland soils irrigated by effluents from biological treatment plants. Environ-Int., 31, 778-783. http://dx.doi.org/10.1016/j.envint.2005.05.024

Cornish, G. A., Mensah, E., \& Ghesquire, P. (1999). Water Quality and Peri-Urban Irrigation: An assessment of surface Quality Water for Irrigation and its Implications for Human in the Per-Urban zone of Kumasi, Ghana. Report OD/TN 95, September 1999, HR Wallingford Ltd., Wallignford, UK., p. 44.

Drechesel, P., Amoah P., \& Abaidoo, R. C. (2005). Irrigated Urban Vegetable Production in Ghana: sources of pathogen contamination and health risk reduction: Irrig. Drainage, 54, 49-61. http://dx.doi.org/10.1002/ird.185

DWAF \& WRC. (1995). South Africa Water Quality Guideline 1: Domestic waste use (2nd ed.), Department of Water Affairs.

Ghesquire, P. (1999). Indirect Wastewater reuses for Peri-Urban Irrigation in Kumasi, Ghana. Assessment of surface water quality for irrigation and its implications for human health. Thesis submitted in partial fulfilment of a Diploma in Water and Environment. ENGEES, Strasburg, France./ HR Wallingford, UK.

Haiyan, W., \& Stuanes, A. O. (2003). Heavy mental pollution in air-water-soil-plant. Water Air Soil Pollut., 147, 79-107. http://dx.doi.org/10.1023/A:1024522111341

Hamilton, A. J., Stagnitti, F., Xiong, X., Kreidl, S. L., Benke, K. K., \& Maher, P. (2007). Reviews and Analyses Wastewater Irrigation: The State of Play. Vadose Zone J., 6, 823-840. http://dx.doi.org/10.2136/vzj2007.0026

Hussein, I., Raschid, L., Hanyara, M. A., Marikar, F., \& van der Heek, W. (2001). A framework for analyzing Sociaeconomic, health and environmental impacts of wastewater use in agriculture in developing countries, working paper 26. Colombo: International Water Management Institute (IWMI Heidapour, M., Mostafazadeh-Fard, B., Adei Koupai, J., Malekian, R., (2007). The effects of treated wastewater on soil chemical properties using sub-surface and surface irrigation methods, Agric. Water Man. 90(1-2), 87-94. (8 pages).

Kandiah, A. (1990a). Water quality management for sustainable agricultural development. Natural Resources Forum, 14(1), 22-32. http://dx.doi.org/10.1111/j.1477-8947.1990.tb00364.x

Koger, S. M., Schettler, T., \& Weiss, B. (2005). Environmental toxicants and developmental disabilities: A challenge for psychologists. Am. Psychol., 60(3), 243-255. http://dx.doi.org/10.1037/0003-066X.60.3.243 
Kocak,, S., Tokusoglu, O., \& Aycan, S. (2005). Some heavy metals and trace essential element detection in canned vegetable foodstuffs by differential pulse polargraphy (DPP). Electronic J. Environ, Agric. Food Chem, 4, 871-878.

Konofal, E., Lecendreux, Arnulf, I., \& Mouren, M. C. (2004). Iron deficiency in children with attention Kachenko, A. G., \& B. Singh. (2006). Heavy metals contamination in vegetables grown in urban and metal smelter contaminated sites in Australia. Water Air Soil Pollut., 169, 101-123.

Mensah., E., Amoah, P., Abaidoo, R. C., \& Drechsel, P. (2001). Environmental concerns of (peri-) urban vegetable production - case studies from Kumasi and Accra. In Drechsel, P., \& Kunze, D. (Eds.). Waste Composting for Urban and Peri-urban Agriculture - Closing the Rural -Urban Nutrient Cycle in sub-Saharan Africa (pp. 55-68). Wallingford, UK: IWMI/FAO/CABI. http://dx.doi.org/10.1079/9780851995489.0055

Pescod, M. D. (1992). Wastewater treatment and use in agriculture. FAO Irrigation and Drainage paper no. 47 (pp. 125-156). Food and Agriculture Organization of the United Nations, Rome, Italy.

Scott, C., Faruqui, N. I., \& Raschid-Sally, L. (2004). Wastewater use in Irrigated Agriculture: Management Challenges in Developing countries. In Scott, C. A. (Ed.), Wastewater use in Irrigated agriculture: Confronting the livelihood and environmental realities. Ottawa, Canada: CAB. http://dx.doi.org/10.1079/9780851998237.0001

Singh, K. P., Mohon, D., Sinha, S., \& Dalwani, R. (2004). Impact assessment of treated/untreated waste water toxicants discharge by sewage treatment plants on health, agricultural and environmental quality in waste water disposal area. Chemosphere, 55, 227-255. http://dx.doi.org/10.1016/j.chemosphere.2003.10.050

Stagnitti, F., Sherwood, J., Allinson, G., Evans, L., Allison, M., Li, L., \& Philips, I. (1998). Ann Investigation of localized soil heterogeneities on solute transport using a multi segment percolation system. New Zealand J. Agric, Res., 41, 603-612. http://dx.doi.org/10.1080/00288233.1998.9513344

Stagnitti, F. (1999). A model of the effects of non-uniform soil-water distribution on the sub-surface migration of bacteria: Implications for land disposal of sewage. Math Computer Mod., 29, 41-52. http://dx.doi.org/10.1016/S0895-7177(99)00038-2

Speijers, G. J. A. (1996). Nitrate in Toxicological evaluation of certain food additive and contaminations in food. WHO Food Additives Series 35, Geneva, pp. 325-360.

Toze, S. (2004). Reuse of effluent water-benefit and risks. CSIRO Land and water. New directions for a plant (p. 4). 4th International Crop Science Congress. Brisbane, Australia.

Weiss, B. (2000). Vulnerability of children and the developing brain to neurotoxic hazards. Env. Health Perspect., 108(3), 375-381. http://dx.doi.org/10.1289/ehp.00108s3375

WHO. (2007). Health Risks of Heavy Metals from Long-Range Transboundary Air Pollution. Joint Task Force on the Health Aspects of Long-range. Transboundary Air Pollution. Geneva.

WHO. (2006). Guidelines for the safe use of wastewater, excreta and grey water: Wastewater use in agriculture. WHO, Geneva, 2, 219.

WHO. (2010). Guidelines for Drinking Water Quality. WHO, Geneva, 1, 130.

Zurera, G., Moreno, R., Salmeron, J., \& Pozo, R. (1989). Heavy metal uptake from greenhouse border soils for edible vegetables. J. Sci. Food Agric., 49, 307-314. http://dx.doi.org/10.1002/jsfa.2740490307 